ORIGINAL ARTICLE

\title{
HUBUNGAN ANTARA AKTIVITAS BELAJAR KELOMPOK DENGAN INDEKS PRESTASI MAHASISWA SEMESTER 6 FAKULTAS KEDOKTERAN UNIVERSITAS HANG TUAH SURABAYA TAHUN AJARAN 2017/2018
}

\author{
Kinanti Hapsari ${ }^{1}$, Efyluk Garianto ${ }^{2}$, Fitri Handajani ${ }^{3}{ }^{*}$ \\ ${ }^{1,2,3}$ Fakultas Kedokteran Universitas Hang Tuah Surabaya \\ *Conrrespondent author: fitrihandajanidr@gmail.com
}

\section{ARTICLE INFO}

Article history:

Submmited: April 162019

Received in revised form

August 2019

Accepted: August 212019

Keywords:

study group, grade point

\begin{abstract}
Background: One of the active learning methods is to do a study group. Researcher is interested in research on the correlation between study group activities and student's grade, so that students can find learning methods which may influence academic outcomes and facilitate learning, especially the medical students. Methods: This observational analytic study was carried out with a cross sectional design. The data of this study were obtained from the answers to the respondent's questionnaire in the Medical Faculty of Hang Tuah University, Surabaya. The sample in this study were semester 6 students of the 2017/2018 academic year at the Faculty of Medicine, University of Hang Tuah Surabaya (130 respondents). Results: Based on the Spearman correlation statistical test between study group activities with the 6th semester students grade point, the significance of the correlation between study group activities and the $6^{\text {th }}$ semester students grade point is 0.687 . With a value of $\alpha=0.05$, means $p>\alpha$, it can be concluded that the correlation between the two variables is not significant so that $\mathrm{H} 0$ accepts and $\mathrm{H} 1$ is rejected. So, there is no correlation between study group activities with $6^{\text {th }}$ semester grade point. Conclusion: There is no correlation between study group activities and the 6th semester students grade point in the Faculty of Medicine, Hang Tuah University Surabaya.
\end{abstract}

@2019 Medical and Health Science Journal. 10.33086/mhsj.v3i2.1070

\section{PENDAHULUAN}

Dalam pelaksanaan pendidikan di Indonesia terdapat beberapa masalah, menurut hasil survei UNESCO pada tahun 2016, minat membaca orang Indonesia sangat rendah. Bahkan dari enam puluh satu negara yang disurvei, Indonesia menempati urutan ke enam puluh dengan tingkat minat $0,001 \%$. Hal ini menggambarkan rendahnya minat dan motivasi belajar masyarakat, terutama mahasiswa Indonesia. Hal ini semakin terbukti dengan pemaparan yang dijabarkan langsung oleh UNESCO bahwa indeks prestasi manusia yang ada pada Indonesia makin menurun. Rendahnya minat dan motivasi belajar akan berdampak pada

Correspondence: Fitri Handajani

@ 2019 Medical and Health Science Journal. 10.33086/mhsj.v3i2.1070

Available at http://journal2.unusa.ac.id/index.php/MHSJ menurunnya keberhasilan pembelajaran seorang mahasiswa.

Indikator keberhasilan pembelajaran seorang mahasiswa salah satunya dapat dilihat dari pencapaian prestasi akademiknya. Faktor intelegensi memiliki peranan penting dalam memperoleh prestasi akademik yang baik. Akan tetapi, faktor aktivitas belajar dan motivasi sama pentingnya bagi mahasiswa untuk meraih prestasi akademik yang lebih baik. Besarnya pengaruh aktivitas belajar mahasiswa juga tergambar dalam penelitian Mcloughlin, dijelaskan bahwa mahasiswa kedokteran dengan tingkat intelegensi tinggi dapat memperoleh prestasi akademik yang rendah jika aktivitas belajarnya kurang terkelola 
dengan baik (Mcloughlin, 2009 disitasi dalam Fitriani, 2012). Dari uraian diatas, demi tercapainya pendidikan di Indonesia yang lebih baik maka salah satu upaya untuk meningkatkan mutu pendidikan adalah dengan mencari metode pembelajaran yang tepat bagi mahasiswa.

Dewasa ini perkembangan metode pembelajaran pada program pendidikan kedokteran banyak yang sudah beralih dari Teacher Centered Learning (TCL) menjadi Student Centered Learning (SCL) dalam proses belajar mengajar, berbagai perguruan tinggi di Indonesia telah menerapkan Kurikulum Berbasis Kompetensi dengan pendekatan Student Centered Learning seperti Problem Based Learning (PBL) sebagai metode pembelajaran (Oktasari, 2018). Salah satu perguruan tinggi yang menerapkan metode pembelajaran Problem Based Learning (PBL) adalah Fakultas kedokteran Universitas Hang Tuah Surabaya. Dengan metode pembelajaran ini para mahasiswa didorong untuk dapat melakukan Self Directed Learning yaitu mencari bahan pembelajaran, kegiatan pembelajaran serta mengevalusi hasil belajar mereka sendiri. Oleh karena itu alokasi waktu mahasiswa untuk belajar mandiri, belajar di perpustakaan maupun belajar kelompok sangat dibutuhkan untuk memaksimalkan pembelajaran mereka (Triastuti, 2016).

Dalam penelitian oleh Triastuti ditemukan bahwa perbedaan waktu belajar mandiri, waktu belajar kelompok, dan waktu belajar di perpustakaan mempengaruhi prestasi akademik mahasiswa kedokteran tahun ke tiga, di mana mahasiswa yang mengalokasikan lebih banyak waktu dalam belajar kelompok (study group) memperoleh prestasi belajar yang lebih tinggi dibandingkan waktu belajar mandiri (self study) dan studi perpustakaan (library study) (Triastuti, 2016). Belajar kelompok yang meliputi problem solving sangat penting dalam pendidikan mahasiswa dalam bidang kesehatan. Belajar kelompok akan melengkapi kuliah, pelajaran/ceramah yang diberikan di perguruan tinggi. Pada belajar kelompok yang efektif, mahasiswa akan berpikir lebih kritis serta terjadi perkembangan dari kemampuan mendengar dan berdiskusi dimana lebih sulit untuk dicapai jika belajar sendiri (Linn, Lord, Whong, \& Phillips, 2013).

Keren et al mengutarakan dalam penelitiannya tiga manfaat dari belajar kelompok, yaitu: 1) belajar kelompok dapat membuat pembelajaran lebih aktif dan menarik. 2) Anggota kelompok dapat saling memberi motivasi dan dapat membantu mahasiswa mengetahui adanya kekurangan ilmu pengetahuannya. 3) Sesama anggota kelompok dapat saling mendukung dan memberi semangat. Meskipun terdapat banyak manfaat dari belajar kelompok, akan tetapi sebagian mahasiswa berpendapat bahwa belajar sendiri lebih efisien, karena belajar kelompok berpotensi untuk mengganggu pembelajaran mereka (Keren et al, 2017).

Dalam pembelajaran di Fakultas Kedokteran Universitas Hang Tuah Surabaya banyak mahasiswa yang membentuk kelompok belajarnya sendiri dan tidak sedikit yang mendapatkan hasil lebih maksimal dibandingkan saat belajar sendiri. Oleh karena itu, berdasarkan uraian di atas menjadi ketertarikan dan dasar bagi peneliti untuk mengadakan penelitian mengenai hubungan antara aktivitas belajar kelompok dengan indeks prestasi mahasiswa, terutama mahasiswa kedokteran agar dapat menemukan metode pembelajaran yang dapat meningkatkan hasil belajar.

\section{METODE PENELITIAN}

Desain penelitian ini adalah analitik observasional yang bertujuan untuk mengetahui hubungan antara aktivitas belajar kelompok dengan indeks prestasi mahasiswa semester 6 Fakultas Kedokteran Universitas Hang Tuah Surabaya Tahun ajaran 2017/2018. Jenis pendekatan yang digunakan adalah cross sectional. Populasi dalam penelitian ini adalah mahasiswa semester 6 Fakultas Kedokteran Universitas Hang Tuah Surabaya Tahun ajaran 2017/2018. Sampel yang diteliti sebagai perwakilan dari populasi diambil dengan metode purposive sampling. Sampel dari penelitian ini didasarkan pada suatu pertimbangan yaitu kriteria 
inklusi dan eksklusi. Pengambilan sampel dilakukan pada responden yaitu mahasiswa angkatan 2015 Fakultas Kedokteran Universitas Hang Tuah Surabaya berjumlah 130 mahasiswa. Alat bantu penelitian agar pelaksanaan observasi mendapat data yang cermat pada penelitian ini adalah menggunakan kuesioner. Penelitian ini dilaksanakan pada bulan Juni - November 2018. Data yang telah dikumpulkan kemudian dianalisis uji statistik Korelasi-Spearman menggunakan SPSS.

\section{HASIL PENELITIAN}

Berdasarkan penelitian yang dilakukan pada 130 responden, maka didapat hasil sebagai berikut :

Tabel 1 Distribusi Responden Berdasarkan Kategori Belajar Kelompok

\begin{tabular}{lll}
\hline $\begin{array}{l}\text { Kategori Belajar } \\
\text { Kelompok }\end{array}$ & Frekuensi (n) & Persentase (\%) \\
\hline Jarang & 64 & 49,2 \\
Sedang & 59 & 45,4 \\
Sering & 7 & 5,4 \\
\hline Total & 130 & 100 \\
\hline
\end{tabular}

Dari tabel 1 diatas dapat diketahui bahwa dari 130 responden sebanyak $64 \quad(49,2 \%)$ mahasiswa masuk dalam kategori jarang, 59(45,4\%) mahasiswa masuk dalam kategori sedang, 7(5,4\%) mahasiswa masuk dalam kategori sering.

Tabel 2 Cross tabulation antara IP semester 6 dan kategori belajar kelompok

\begin{tabular}{|c|c|c|c|c|c|}
\hline & \multicolumn{5}{|c|}{ Kategori } \\
\hline $\begin{array}{c}\text { Sem } \\
6\end{array}$ & & Jarang & Sedang & Sering & Total \\
\hline $\mathbf{1 . 5 0}$ & $\mathrm{F}$ & 0 & 1 & 0 & 1 \\
\cline { 2 - 6 } & $\%$ & $0 \%$ & $0.8 \%$ & $0 \%$ & $0.8 \%$ \\
\hline 2.50 & $\mathrm{~F}$ & 2 & 0 & 0 & 2 \\
\cline { 2 - 6 } & $\%$ & $1.5 \%$ & $0 \%$ & $0 \%$ & $1.5 \%$ \\
\hline
\end{tabular}

\begin{tabular}{|c|c|c|c|c|c|}
\hline \multirow[t]{2}{*}{2.60} & $F$ & 1 & 0 & 0 & 1 \\
\hline & $\%$ & $0.8 \%$ & $0 \%$ & $0 \%$ & $0.8 \%$ \\
\hline \multirow[t]{2}{*}{2.70} & $F$ & 0 & 1 & 0 & 1 \\
\hline & $\%$ & $0 \%$ & $0.8 \%$ & $0 \%$ & $0.8 \%$ \\
\hline \multirow[t]{2}{*}{2.73} & $F$ & 1 & 0 & 0 & 1 \\
\hline & $\%$ & $0.8 \%$ & $0 \%$ & $0 \%$ & $0.8 \%$ \\
\hline \multirow[t]{2}{*}{2.75} & $F$ & 1 & 0 & 0 & 1 \\
\hline & $\%$ & $0.8 \%$ & $0 \%$ & $0 \%$ & $0.8 \%$ \\
\hline \multirow[t]{2}{*}{2.80} & $F$ & 0 & 2 & 0 & 2 \\
\hline & $\%$ & $0 \%$ & $1.5 \%$ & $0 \%$ & $1.5 \%$ \\
\hline \multirow[t]{2}{*}{2.90} & $F$ & 2 & 0 & 0 & 2 \\
\hline & $\%$ & $1.5 \%$ & $0 \%$ & $0 \%$ & $1.5 \%$ \\
\hline \multirow[t]{2}{*}{2.92} & $F$ & 0 & 1 & 0 & 1 \\
\hline & $\%$ & $0 \%$ & $0.8 \%$ & $0 \%$ & $0.8 \%$ \\
\hline \multirow[t]{2}{*}{2.95} & F & 0 & 1 & 0 & 1 \\
\hline & $\%$ & $0 \%$ & $0.8 \%$ & $0 \%$ & $0.8 \%$ \\
\hline \multirow{2}{*}{3.00} & $F$ & 7 & 3 & 1 & 11 \\
\hline & $\%$ & $5.4 \%$ & $2.3 \%$ & $0.8 \%$ & $8.5 \%$ \\
\hline \multirow[t]{2}{*}{3.05} & $F$ & 1 & 0 & 0 & 1 \\
\hline & $\%$ & $0.8 \%$ & $0 \%$ & $0 \%$ & $0.8 \%$ \\
\hline \multirow[t]{2}{*}{3.10} & $F$ & 2 & 5 & 1 & 8 \\
\hline & $\%$ & $1.5 \%$ & $3.8 \%$ & $0.8 \%$ & $6.2 \%$ \\
\hline \multirow[t]{2}{*}{3.50} & $F$ & 4 & 3 & 1 & 8 \\
\hline & $\%$ & $3.1 \%$ & $2.3 \%$ & $0.8 \%$ & $6.2 \%$ \\
\hline \multirow[t]{2}{*}{3.51} & $F$ & 1 & 0 & 0 & 1 \\
\hline & $\%$ & $0.8 \%$ & $0 \%$ & $0 \%$ & $0.8 \%$ \\
\hline \multirow[t]{2}{*}{3.53} & $F$ & 0 & 1 & 0 & 1 \\
\hline & $\%$ & $0 \%$ & $0.8 \%$ & $0 \%$ & $0.8 \%$ \\
\hline \multirow[t]{2}{*}{3.54} & $F$ & 0 & 1 & 0 & 1 \\
\hline & $\%$ & $0 \%$ & $0.8 \%$ & $0 \%$ & $0.8 \%$ \\
\hline \multirow[t]{2}{*}{3.55} & $F$ & 2 & 0 & 0 & 2 \\
\hline & $\%$ & $1.5 \%$ & $0 \%$ & $0 \%$ & $1.5 \%$ \\
\hline \multirow[t]{2}{*}{3.57} & $F$ & 1 & 0 & 0 & 1 \\
\hline & $\%$ & $0.8 \%$ & $0 \%$ & $0 \%$ & $0.8 \%$ \\
\hline \multirow[t]{2}{*}{3.58} & $F$ & 1 & 1 & 0 & 2 \\
\hline & $\%$ & $0.8 \%$ & $0.8 \%$ & $0 \%$ & $1.5 \%$ \\
\hline \multirow[t]{2}{*}{3.59} & $F$ & 0 & 1 & 0 & 1 \\
\hline & $\%$ & $0 \%$ & $0.8 \%$ & $0 \%$ & $0.8 \%$ \\
\hline
\end{tabular}




\begin{tabular}{|c|c|c|c|c|c|}
\hline \multirow[t]{2}{*}{3.60} & $F$ & 5 & 0 & 1 & 6 \\
\hline & $\%$ & $3.8 \%$ & $0 \%$ & $0.8 \%$ & $4.8 \%$ \\
\hline \multirow[t]{2}{*}{3.62} & $\bar{F}$ & 0 & 1 & 0 & 1 \\
\hline & $\%$ & $0 \%$ & $0.8 \%$ & $0 \%$ & $0.8 \%$ \\
\hline \multirow[t]{2}{*}{3.64} & $\mathrm{~F}$ & 0 & 1 & 0 & 1 \\
\hline & $\%$ & $0 \%$ & $0.8 \%$ & $0 \%$ & $0.8 \%$ \\
\hline \multirow[t]{2}{*}{3.65} & $F$ & 2 & 1 & 0 & 3 \\
\hline & $\%$ & $1.5 \%$ & $0.8 \%$ & $0 \%$ & $2.3 \%$ \\
\hline \multirow[t]{2}{*}{3.67} & $F$ & 0 & 2 & 0 & 2 \\
\hline & $\%$ & $0 \%$ & $1.5 \%$ & $0 \%$ & $1.5 \%$ \\
\hline \multirow[t]{2}{*}{3.69} & $\mathbf{F}$ & 1 & 0 & 0 & 1 \\
\hline & $\%$ & $0.8 \%$ & $0 \%$ & $0 \%$ & $0.8 \%$ \\
\hline \multirow[t]{2}{*}{3.70} & $\mathbf{F}$ & 2 & 2 & 1 & 5 \\
\hline & $\%$ & $1.5 \%$ & $1.5 \%$ & $0.8 \%$ & $3.8 \%$ \\
\hline \multirow[t]{2}{*}{3.72} & $\mathbf{F}$ & 1 & 1 & 0 & 2 \\
\hline & 96 & $0.8 \%$ & $0.8 \%$ & $0 \%$ & $1.5 \%$ \\
\hline \multirow[t]{2}{*}{3.74} & $F$ & 1 & 2 & 0 & 3 \\
\hline & $9 \%$ & $0.8 \%$ & $1.5 \%$ & $0 \%$ & $2.3 \%$ \\
\hline \multirow[t]{2}{*}{3.75} & $F$ & 1 & 1 & 1 & 3 \\
\hline & $\%$ & $0.8 \%$ & $0.8 \%$ & $0.8 \%$ & $2.3 \%$ \\
\hline \multirow[t]{2}{*}{3.77} & $\bar{F}$ & 0 & 1 & 0 & 1 \\
\hline & $\%$ & $0 \%$ & $0.8 \%$ & $0 \%$ & $0.8 \%$ \\
\hline \multirow[t]{2}{*}{3.80} & $\bar{F}$ & 1 & 1 & 1 & 3 \\
\hline & 96 & $0.8 \%$ & $0.8 \%$ & $0.8 \%$ & $2.3 \%$ \\
\hline \multirow[t]{2}{*}{3.82} & $F$ & 0 & 1 & 0 & 1 \\
\hline & $\%$ & $0 \%$ & $0.8 \%$ & $0 \%$ & $0.8 \%$ \\
\hline \multirow[t]{2}{*}{3.85} & $F$ & 0 & 1 & 0 & 1 \\
\hline & $\%$ & $0 \%$ & $0.8 \%$ & $0 \%$ & $0.8 \%$ \\
\hline \multirow[t]{2}{*}{3.90} & $F$ & 1 & 0 & 0 & 1 \\
\hline & $\%$ & $0.8 \%$ & $0 \%$ & $0 \%$ & $0.8 \%$ \\
\hline \multirow[t]{2}{*}{3.92} & $F$ & 2 & 1 & 0 & 3 \\
\hline & $\%$ & $1.5 \%$ & $0.8 \%$ & $0 \%$ & $2.3 \%$ \\
\hline \multirow[t]{2}{*}{3.94} & $F$ & 2 & 0 & 0 & 2 \\
\hline & $\%$ & $1.5 \%$ & $0 \%$ & $0 \%$ & $1.5 \%$ \\
\hline \multirow[t]{2}{*}{3.95} & $F$ & 1 & 0 & 0 & 1 \\
\hline & $\%$ & $0.8 \%$ & $0 \%$ & $0 \%$ & $0.8 \%$ \\
\hline \multirow[t]{2}{*}{4.00} & $F$ & 1 & 2 & 0 & 3 \\
\hline & $9 \%$ & $0.8 \%$ & $1.5 \%$ & $0 \%$ & $2.3 \%$ \\
\hline \multirow[t]{2}{*}{ Total } & $F$ & 84 & 59 & 7 & 130 \\
\hline & $9 \%$ & $42.9 \%$ & $45.4 \%$ & $5.4 \%$ & $100 \%$ \\
\hline
\end{tabular}

\begin{tabular}{|c|c|c|c|c|c|}
\hline \multirow{2}{*}{3.15} & $\mathbf{F}$ & 1 & 1 & 0 & 2 \\
\hline & $\%$ & $0.8 \%$ & $0.8 \%$ & $0 \%$ & $1.5 \%$ \\
\hline \multirow[t]{2}{*}{3.18} & $\mathbf{F}$ & 1 & 0 & 0 & 1 \\
\hline & $\%$ & $0.8 \%$ & $0 \%$ & $0 \%$ & $0.8 \%$ \\
\hline \multirow[t]{2}{*}{3.20} & $\bar{F}$ & 2 & 2 & 0 & 4 \\
\hline & $\%$ & $1.5 \%$ & $1.5 \%$ & $0 \%$ & $3.1 \%$ \\
\hline \multirow[t]{2}{*}{3.23} & $\mathbf{F}$ & 0 & 1 & 0 & 1 \\
\hline & $\%$ & $0 \%$ & $0.8 \%$ & $0 \%$ & $0.8 \%$ \\
\hline \multirow[t]{2}{*}{3.28} & $\mathbf{F}$ & 0 & 1 & 0 & 1 \\
\hline & $\%$ & $0 \%$ & $0.8 \%$ & $0 \%$ & $0.8 \%$ \\
\hline \multirow[t]{2}{*}{3.30} & $\mathbf{F}$ & 3 & 8 & 0 & 9 \\
\hline & $\%$ & $2.3 \%$ & $4.8 \%$ & $0 \%$ & $6.9 \%$ \\
\hline \multirow[t]{2}{*}{3.32} & $\mathbf{F}$ & 1 & 0 & 0 & 1 \\
\hline & $\%$ & $0.8 \%$ & $0 \%$ & $0 \%$ & $0.8 \%$ \\
\hline \multirow[t]{2}{*}{3.33} & $\mathbf{F}$ & 1 & 1 & 0 & 2 \\
\hline & $\%$ & $0.8 \%$ & $0.8 \%$ & $0 \%$ & $1.5 \%$ \\
\hline \multirow[t]{2}{*}{3.35} & $\mathbf{F}$ & 1 & 0 & 0 & 1 \\
\hline & $\%$ & $0.8 \%$ & $0 \%$ & $0 \%$ & $0.8 \%$ \\
\hline \multirow[t]{2}{*}{3.36} & $F$ & 0 & 1 & 0 & 1 \\
\hline & $\%$ & $0 \%$ & $0.8 \%$ & $0 \%$ & $0.8 \% 6$ \\
\hline \multirow[t]{2}{*}{3.37} & $\mathbf{F}$ & 0 & 2 & 0 & 2 \\
\hline & $\%$ & $0 \%$ & $1.5 \%$ & $0 \%$ & $1.5 \%$ \\
\hline \multirow[t]{2}{*}{3.40} & $F$ & 5 & 3 & 0 & 8 \\
\hline & $\%$ & $3.8 \%$ & $2.3 \%$ & $0 \%$ & $6.2 \%$ \\
\hline \multirow[t]{2}{*}{3.43} & $F$ & 1 & 0 & 0 & 1 \\
\hline & $\%$ & $0.8 \%$ & $0 \%$ & $0 \%$ & $0.8 \%$ \\
\hline \multirow[t]{2}{*}{3.45} & $F$ & 1 & 1 & 0 & 2 \\
\hline & $\%$ & $0.8 \%$ & $0.8 \%$ & $0 \%$ & $1.5 \%$ \\
\hline \multirow[t]{2}{*}{3.47} & $\mathbf{F}$ & 0 & 1 & 0 & 1 \\
\hline & $\%$ & $0 \%$ & $0.8 \%$ & $0 \%$ & $0.8 \%$ \\
\hline
\end{tabular}

Dari Tabel 2 tabulasi silang antara IP semester 6 dengan kategori aktivitas belajar kelompok mahasiswa semester 6 Fakultas Kedokteran Universitas Hang Tuah Surabaya Tahun Ajaran 2017/2018. Berdasarkan uji cr silang, mahasiswa dengan indeks prestasi kurang dari 3,00 yang aktivitas belajar kelompoknya masuk dalam kategori jarang berjumlah 7 orang, yang termasuk dalam kategori sedang berjumlah 6 orang dan yang termasuk sering tidak ada. Mahasiswa dengan indeks prestasi 3,00 - 3,49 
yang aktivitas belajar kelompoknya termasuk dalam kategori jarang 27 orang, yang termasuk sedang berjumlah 28 orang dan yang termasuk sering berjumlah 2 orang. Kemudian mahasiswa dengan indeks prestasi 3,50 - 3,79 yang aktivitas belajar kelompoknya termasuk dalam kategori jarang berjumlah 22 orang, yang termasuk dalam kategori sedang berjumlah 19 orang dan yang masuk dalam kategori sering berjumlah 4 orang. Sedangkan mahasiswa dengan indeks prestasi lebih dari 3,80 yang aktivitas belajar kelompoknya masuk dalam kategori jarang berjumlah 8 orang, yang masuk dalam kategori sedang 6 orang dan yang masuk dalam kategori sering berjumlah 1 orang. Dalam penelitian ini indeks prestasi sebenarnya berskala rasio, tetapi penulis membagi indeks prestasi menjadi beberapa kategori dengan tujuan untuk memudahkan pembahasan. Dapat dilihat bahwa mahasiswa dengan indeks prestasi lebih dari 3,80 kebanyakan memiliki aktivitas belajar kelompok yang masuk dalam kategori jarang. Sehingga dapat disimpulkan bahwa tinggi rendahnya indeks prestasi mahasiswa tidak dipengaruhi oleh aktivitas belajar kelompok.

\section{UJI STATISTIK}

Tabel 3 Hasil Uji Korelasi Spearman

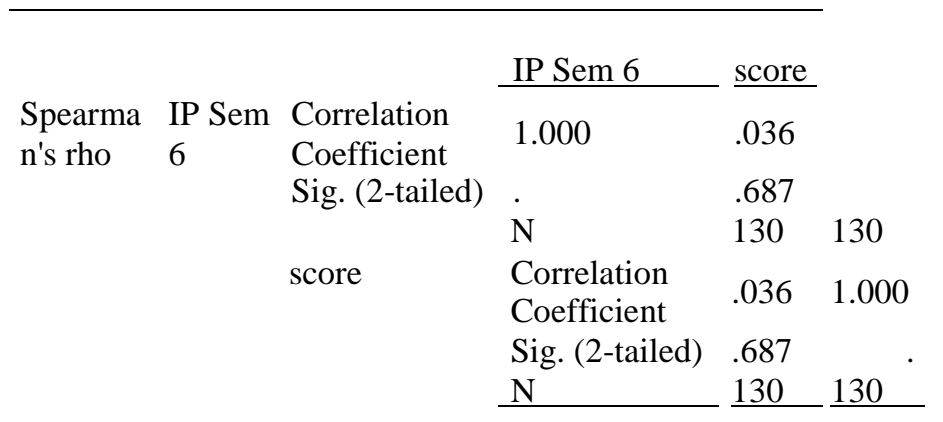

Berdasarkan tabel 3 dapat diketahui bahwa nilai signifikansi $(p)=0,687$ yang berarti $p$ $>\quad \propto$ (dengan $\quad \propto=0,05)$ yang artinya $\mathrm{H} 0$ diterima dan $\mathrm{H} 1$ ditolak. Jadi, tidak ada hubungan antara aktivitas belajar kelompok dengan indeks prestasi mahasiswa semester 6 Fakultas Kedokteran Universitas Hang Tuah Surabaya tahun ajaran 2017/2018.

\section{PEMBAHASAN}

Dari penelitian yang dilakukan terhadap 130 mahasiswa semester 6 tahap pre-klinik Fakultas Kedokteran Universitas Hang Tuah Surabaya tahun ajaran 2017/2018, diperoleh jumlah mahasiswa yang belajar kelompoknya masuk dalam kategori jarang sebanyak 64 $(49,2 \%)$ mahasiswa, mahasiswa yang masuk dalam kategori sedang sebanyak 59 (45,4\%) mahasiswa, dan mahasiswa yang masuk dalam kategori sering sebanyak $7(5,4 \%)$ mahasiswa.

Berdasarkan uji statistik korelasi Spearman antara aktivitas belajar kelompok dengan indeks prestasi semester 6 didapatkan hasil, signifikansi hubungan antara aktivitas belajar kelompok dengan indeks prestasi semester 6 adalah 0,687. Dengan nilai $\alpha=0.05$, berarti $p>\alpha$, maka dapat disimpulkan bahwa hubungan antara dua variabel tersebut tidak signifikan sehingga $\mathrm{H} 0$ terima dan H1 ditolak. Jadi, tidak terdapat hubungan antara antara aktivitas belajar kelompok dengan indeks prestasi semester 6. Hal ini tidak sesuai dengan penelitian yang dilakukan oleh (Hidayati, 2010) dengan judul "Hubungan Aktifitas Belajar Kelompok Dengan Prestasi Belajar Siswa Madrasah Tsanawiyah Negeri Umbulsari Kabupaten Jember" dan penelitian "Pengaruh Belajar Kelompok dan Motivasi Belajar Siswa Terhadap Prestasi Belajar Siswa Kelas VIII SMP Negeri 23 Purworejo" yang dilakukan oleh (Putriana, 2013) yang hasilnya berdasarkan analisis diperoleh pengaruh variabel belajar kelompok terhadap prestasi belajar siswa sebesar 13,25\% maka dapat dikatakan signifikan, berarti hipotesis berbunyi ada pengaruh yang positif dan signifikan antara belajar kelompok terhadap prestasi belajar, dapat diterima yang artinya semakin tinggi aktivitas belajar kelompok maka akan semakin baik pula prestasi belajar siswa.

Tidak adanya Hubungan antara aktivitas belajar kelompok dengan indeks prestasi mahasiswa pada penelitian ini mungkin di pengaruhi oleh banyak faktor. Aktivitas belajar kelompok dibentuk oleh beberapa hal, yang paling utama adalah keterlibatan mahasiswa dalam belajar kelompok, frekuensi belajar 
kelompok dan juga tingkat konsentrasi mahasiswa selama belajar kelompok. Keterlibatan mahasiswa dalam belajar kelompok dinilai dari peran mahasiswa dalam belajar kelompok. frekuensi dinilai dari berapa kali mahasiswa belajar kelompok dalam satu minggu, Sedangkan tingkat konsentrasi dinilai dari berapa persen fokus dalam materi kuliah selama dua jam belajar kelompok.

Peran mahasiswa dalam belajar kelompok akan membuat hasil belajar yang berbeda. Hal ini didukung oleh teori piramida pembelajaran yang dikemukakan oleh Egdar Dale tahun 1969 yaitu model pembelajaran dibagi menjadi dua: aktif dan pasif. Pembelajaran pasif termasuk didalamnya adalah membaca, mendengar dan melihat hanya memberi andil penguasaan materi sebanyak 10-30\%, sedangkan model pembelajaran aktif yaitu diskusi kelompok, praktik dan mengajar orang lain berkontribusi 5090\% terhadap pemahaman seseorang terhadap materi pelajaran (BPPK, 2013). Peneliti membagi peran belajar kelompok menjadi pendengar, pencatat hasil belajar, pengajar dan pemimpin diskusi. Pendengar dan pencatat hasil belajar temasuk pembelajaran pasif sedangkan pengajar dan pemimpin diskusi termasuk pembelajaran aktif. Berdasarkan hasil kuesioner dan pengamatan peneliti bahwa kebanyakan mahasiswa berperan sebagai pendengar.

Frekuensi belajar dianalisa dari jumlah belajar kelompok dalam satu minggu, ditemukan hasil sebanyak 52 (40\%) mahasiswa tidak belajar kelompok dalam satu minggu, 46 (35,4\%) mahasiswa belajar kelompok satu kali dalam satu minggu, 26 (20\%) mahasiswa belajar kelompok dua kali dalam satu minggu, $6(4,6 \%)$ mahasiswa belajar kelompok tiga kali dalam satu minggu. Dari hasil data dapat disimpulkan bahwa mahasiswa paling banyak hanya belajar kelompok satu kali dalam seminggu. Menurut pengamatan peneliti hal ini mungkin disebabkan karena kebanyakan mahasiswa dengan indeks prestasi >3.80 sudah mendapatkan metode belajarnya yang lebih efektif dari belajar kelompok. Frekuensi belajar merupakan suatu hal yang penting dalam meningkatkan prestasi belajar mahasiswa. Dalam belajar yang dibutuhkan adalah belajar sesering mungkin tetapi efektif daripada belajar dalam waktu yang lama tetapi tidak efektif. Pada penelitian (Nurulita, 2014) dengan judul "Hubungan Frekuensi Belajar Dan Kepercayaan Diri Dengan Prestasi Belajar Melakukan Proses Administrasi Transaksi Siswa Kelas XI SMK Kasatrian Solo Sukoharjo Tahun Pelajaran 2013/2014" terdapat hubungan yang positif antara variabel frekuensi belajar dengan prestasi belajar. Semakin sering belajar maka penguasaan terhadap materi akan semakin baik.

Tingkat konsentrasi yang dianalisa adalah distribusi berapa persen fokus responden pada materi kuliah selama belajar kelompok dalam 2 jam belajar kelompok. Pada distribusi mahasiswa yang belajar kelompok sebagian besar fokus sebanyak 50\% dalam 2 jam belajar kelompok 39 (30\%), kemudian yang fokus $75 \%$ dalam 2 jam belajar kelompok sebanyak 25 (19,2\%). Sedangkan mahasiswa yang fokus $100 \%$ dalam 2 jam belajar kelompok hanya $1(0,8 \%)$ orang. Dari data diatas dapat disimpulkan bahwa masih kurangnya konsentrasi mahasiswa pada materi kuliah selama belajar kelompok. Menurut hasil pengamatan peneliti dan hasil wawancara masih banyak mahasiswa yang menggunakan waktu belajar kelompoknya malah sebagai tempat untuk mengobrol atau melakukan aktivitas lain. Terdapat juga faktor-faktor lain yang dapat mengganggu konsentrasi belajar kelompok yang tidak diteliti.

Keterbatasan penelitian ini adalah keterbatasan waktu dan pengambilan data yang menggunakan kuesioner yang membutuhkan kejujuran dari responden untuk mengetahui kebenaran data.

\section{KESIMPULAN}

1. Tidak ada hubungan antara aktivitas belajar kelompok dengan indeks prestasi mahasiswa semester 6 Fakultas Kedokteran Universitas Hang Tuah Surabaya Tahun Ajaran 2017/2018. 
2. Aktivitas belajar kelompok mahasiswa Fakultas Kedokteran Universitas Hang Tuah Surabaya Tahun Ajaran 2017/2018 sebagian besar masuk dalam kategori jarang belajar kelompok.

\section{DAFTAR PUSTAKA}

1. Hidayati, E. (2010). Hubungan Aktifitas Belajar Kelompok Dengan Prestasi Belajar Siswa Madrasah Tsanawiyah Negeri Umbulsari Kabupaten Jember, 2009.

2. Keren, D., Lockyer, J., \& Ellaway, R. H. (2017). Social studying and learning among medical students: a scoping review. Perspectives on Medical Education, 6(5), 311318. https://doi.org/10.1007/s40037-017-0358-9

3. Linn, W. D., Lord, K. C., Whong, C. Y., \& Phillips, E. G. (2013). Developing effective study groups in the quest for the "holy grail": Critical thinking. American Journal of Pharmaceutical Education, 77(8), 2013. https://doi.org/10.5688/ajpe778180

4. Nurulita, S. (2014). Hubungan Frekuensi
Belajar Dan Kepercayaan Diri DENGAN Prestasi Belajar Melakukan Proses Administrasi Transaksi Siswa Kelas XI SMK Kasatrian Solo Sukoharjo Tahun Pelajaran 2013/2014.

5. Oktasari, N. A. (2018). Hubungan kuliah dan belajar kelompok pada step VI metode PBL terhadap pencapaian prestasi belajar mahasiswa fakultas kedokteran Universitas Muhammadiyah Surakarta.

6. Putriana, S. (2013). Pengaruh Belajar Kelompok dan Motivasi Belajar Siswa Terhadap Prestasi Belajar Siswa Kelas viii SMP Negeri 23 Purworejo.

7. Triastuti, N. J. (2016). The Influence of SelfStudy Time, Group Study Time and Library Study Time on Academic Achievement of Medical Students Applying Problem Based Learning, 3(14), 713-721. 